Stefanie RÖßLER

\section{Green space development in shrinking cities: opportunities and constraints}

\section{Introduction: impacts of shrinkage to green space development}

\subsection{Shrinking cities in Eastern Germany}

Many cities in Eastern Germany are affected by processes of demographic and economic shrinkage (Hannemann, 2003; Gatzweiler et al., 2003): (1) Demographic processes mean changes in the size and structure of the population. Lower fertility rates have been causing the absolute population to drop. A rising level of life expectancy has lead to demographic aging. Additionally, internal migration has resulted in regional population decline. Meanwhile, immigration and changing lifestyles have made populations more international and heterogeneous. (2) Deindustrialisation in Eastern Germany has led to economic problems and has also resulted in declining budgets of the local authorities. (3) Loss of population and economic downturn have brought about a fall in the demand for housing, commercial property and social infrastructure buildings, thus creating a surplus. The increasing number of vacancies calls for the demolition of buildings, producing more empty spaces and transforming the urban fabric. Concurrent suburbanisation and changes in land-usage have reduced the spatial density of shrinking cities.

Shrinking phenomena impact various aspects of urban development in diverse ways. From a spatial perspective, the most pressing problems are the vacancies in housing and commercial properties, the demolition of buildings and the increase in vacant lots, since less redevelopment is required. The spatial effects of shrinking are countered by various policy measures and joint federal and state programmes. The government grants financial aid to affected real estate owners and public utilities to demolish surplus housing stock and obsolete infrastructure, and enhance the affected quarters (e.g. the programme "Urban Restructuring in Eastern Germany").

\subsection{Urban Restructuring and Green Space Development}

Urban restructuring is regarded as a strategic response to the current situation and as a way of improving the quality of life and of enhancing sustainable development in shrinking cities by revitalising urban areas. Green spaces are meant to provide an answer as to what should be done with the resulting open spaces and are also intended to be intrinsic parts of a sustainable city. The increasing number of open spaces implies opportunities for the long-term development of green spaces and satisfying environmental demands. These challenges are confronted by manifold barriers in planning practice: shrinking processes and restructuring practices have fundamentally changed the conditions not only for the shape and function of future urban green spaces but also for the implementation, organisation and funding of green space planning (Rößler, 2007).

\subsection{Shrinkage as framework for green space development}

Shrinking processes influence green space development and planning in diverse ways.

\section{Demographic change}

The effects of demographic change - as one of the main characteristics of shrinkage - may change the intensity and also the ways of using green spaces:

1. Decreasing numbers of (potential) users according to decreasing population firstly may improve the quality of use, avoid overuse, vandalism and avoid conflicts between groups of users caused by different demands. We are used to set minimum standards to ensure the equal provision of high quality green spaces for the urban population. Now the paradigms are changing: We have to think about emptiness, feelings of fear and missing social interactions in green spaces. It's hard to set benchmarks which define a minimal number of users. But political decisions and support also depend on the degree of utilisation. Regarding political decision processes according financial support for green spaces the lack of users may lead to the reduction of financing for maintenance or even closing of special green spaces (e. g sports facilities or playgrounds).

2. According the changes in population structure - namely diversification, singularisation, differentiation and ageing demands for green space use may change. An ageing society calls for green space offers nearby living quarters. Practices in using green spaces and behaviour may differentiate in multiethnic societies. Green Spaces therefore have to fulfil a number of changing requirements. This can also be reflected in a growing diversity of shapes and types of urban green spaces.

\section{Legal framework}

According changing planning paradigms the legal framework has been adapted. Although the new approach of urban restructuring was implemented in the planning and building law a number of legal restrictions hinder the realisation of green spaces regardless the necessity. Remaining building rights on former built estates and relating high land values restrict long term green space development.

\section{Shortage of money}

Relating to demographic change widely economic difficulties restrict the widespread realisation of green spaces on empty land. Private and also municipal financial resources are continually decreasing. According to the questionable 
degree of utilisation this means the most restrictive framework for future green space development.

So unless the growing amount of potential green spaces the legal, economic and also planning framework partly constrain the possibilities of green space development. Future green space planning in shrinking cities has to deal with those challenges. As a result new strategies and planning approaches have to be developed. New types of green spaces according their shape and function have to be adjoined by new ways of implementation, organisation, funding and responsibilities.

\section{Research interests and methodology}

Vacant lots mean opportunities and challenges for green space development. The increasing amount of open spaces implies opportunities for the long term development of green spaces: realisation of basic green systems within the urban fabric, improvement of the residential environment and the integration of ecological needs. Against this backdrop the question is whether the influence and significance of green spaces and their development needs will change and whether they will affect urban planning. The main points of interest are:

- Is there an increasing amount of attention being paid to green space topics in models and visions for urban development?

- Does institutional green space planning develop its own or new green space strategies in response to the opportunities and challenges of shrinkage?

- How is the relationship characterised between green space planning and urban planning?

The research has based on a theoretical discussion of (1) urbanisation models in historical and current urban planning, (2) the urban relationship to nature and (3) the perception of urban landscapes. By means of derived suppositions from the theoretical discussion, an embedded case study using three units of analysis was carried out. Three large cities of Eastern Germany (Leipzig, Halle and Chemnitz) were selected as representative shrinking cities with experience in green space development under current conditions. As a basis for qualitative empirical research, the following data were used: municipal documents regarding urban planning and green space planning, master plans for the whole city and shrinking districts and concrete projects of urban restructuring and urban green space planning. Additionally, local representatives of each city council were interviewed, focusing on their experiences and perceptions regarding green space development as a challenge in their shrinking city.

\section{Role of green spaces in urbanisation models and city strategies}

\subsection{Urbanisation models}

The new spatial framework, characterised by a growing dimension of open spaces, has led to urban structural models which include explicit propositions regarding the distribution of unavoidable open and green spaces. In the context of the theoretical discussion, four basic urban models under shrinking conditions are differentiated: compact city, fragmented city, perforated city and disintegrated city (Albers, 2007; Doehler-Behzadi, Schiffers, 2004; Blume, 2005; Reuther, 2002).

The relevance of green spaces according their amount, distribution, function and potential characteristic is strongly related to the urbanisation model and therefore the spatial structure of a city.

Compact urban structures mean a strong division of inner densely built up areas and the surrounding landscape. The situation will be characterised by a lack of green spaces. The chance to develop green space systems as a network of different green spaces is missed. Outside the citiy borders natural open spaces can be preserved.

A more fragmented city ensures stable areas with a density of buildings and uses. The concentration of decreasing uses on urban islands includes the necessity of forming the remaining open spaces as a green surrounding or even stable network which ensures the cohesion and perception of the urban area.

Uncontrolled perforation, by demolition of empty buildings and infrastructure, leads to the perforated city. Coincidental developing open spaces produce disperse urban structures. Decay and emptiness characterise these type of shrinking city. Although these processes are neither planned nor supported, the spatial reality in shrinking cities can partly be described by perforation. Open and also green spaces are distributed according the demolition of buildings not following any planning strategies or real demands. They are temporary fragments. If they are designed or maintained even on low level they may lead to short term improvements of green space provision. But they won't get equal elements of urban structure.

The extreme development following the perforation may lead to the disintegrated city. Urban cohesion is more and more getting lost and open spaces become the defining structure of urban areas. In that way they are more a green ground for more or less isolated built structures, loosing their quality of an urban element. Honestly this model is more a hypothetical one - in strong shrinking quarters partly these development can be foreseen.

These general models form the basis for specific urban structural models in shrinking cities. The spatial vision of each city more or less reflects these basic ideas, depending on the historic urban structure, the local topography, the distribution and the location of shrinking districts and vacant housing stock. The venues of the spatial shrinkage influence the framework for urban green space development. Attempts are being made to realise the vision of the compact European city in historic city centres at the expense of the perforation or fragmentation of the outer districts. Aware that a dense urban structure cannot be kept all over the whole city area, the model of a more fragmented urban structure with urban cores and connected green spaces is being aimed at in parts of the city. This means a really new approach and perception: 
The model of the "European City" which is characterised by dense urban structures has been one of the most relevant ideals of city development. Under shrinking conditions this ideal idea of the urban form hasn't lost its power - as lot examples show. But against the background of shrinkage pressures and the need for demolition and restructuring also other models of city form get important. The protection of dense structures at least in the city centre calls for shrinking processes in the inner city and also the urban fringe. As a consequence also models of more fragmented or perforated urban structures have been accepted in the analysed cities.

\subsection{Green spaces in strategies of urban restructuring}

To avoid a negative perception caused by demolition and decay green space development might be a strategy to foster a positive image also under shrinking conditions. Green spaces promise a good quality of life and urban environment and therefore underline also positive impacts of shrinkage, which is mainly perceived as a negative process. Additionally they provide a land use which offers fast, widely accepted and relationally cheap solutions for plots without any necessity to be rebuilt. Urban development concepts which include strategic objectives for city development under shrinking conditions often formulate the advantages for green space provision which accompany shrinking processes. Therefore objectives for green space development and the opportunities for more liveable greener cities play an important role on the strategic level of city development. But the chances and efforts which are being made to realise these objectives are getting smaller during the process of urban restructuring: As described before in the beginning of the restructuring process green spaces are acceptable solutions and options for the arising vacant lots. The decision process about where and which buildings will be demolished is mostly influenced by economic and legal aspects and the belongings of the owner rather than by spatial or even green space planning aspects. This results in the need for measures and investments of green space planning independent from overall spatial green space strategies. Although projects of green space development are relatively cheap compared to different building activities even these less costs mean problems for municipalities and landowners. For that reason increasingly one look for solutions which are profitable or at least cost-covering.

At the end green space development is discussed regarding cost effectiveness and as a way for the exploitation of space. It's less the quality and the benefits of green spaces especially in shrinking cities than the pressures and barriers which define the discussion.

These developments can be watched in several cities: During the planning and later realisation of demolition green space belongings are in fact getting more important but the restrictions and burdens are also getting more. Although green spaces firstly have been seen as simple and also good solutions - this promise cannot be fulfilled in any case or respectively automatically. Political willingness also has to be adjoined by support, financial resources and voice of the sectoral planning.

\subsection{Strategies of green space planning in shrinking cities}

A general difference has to be made between permanent and temporary development of green spaces on derelict land (figures 1, 2). In light of the fact that there is no shortterm demand for buildings of residential or commerce, green spaces are acceptable as a form of temporary improvement. The significance of these temporary green spaces and their enhancement in strategies of urban renewal is very high.

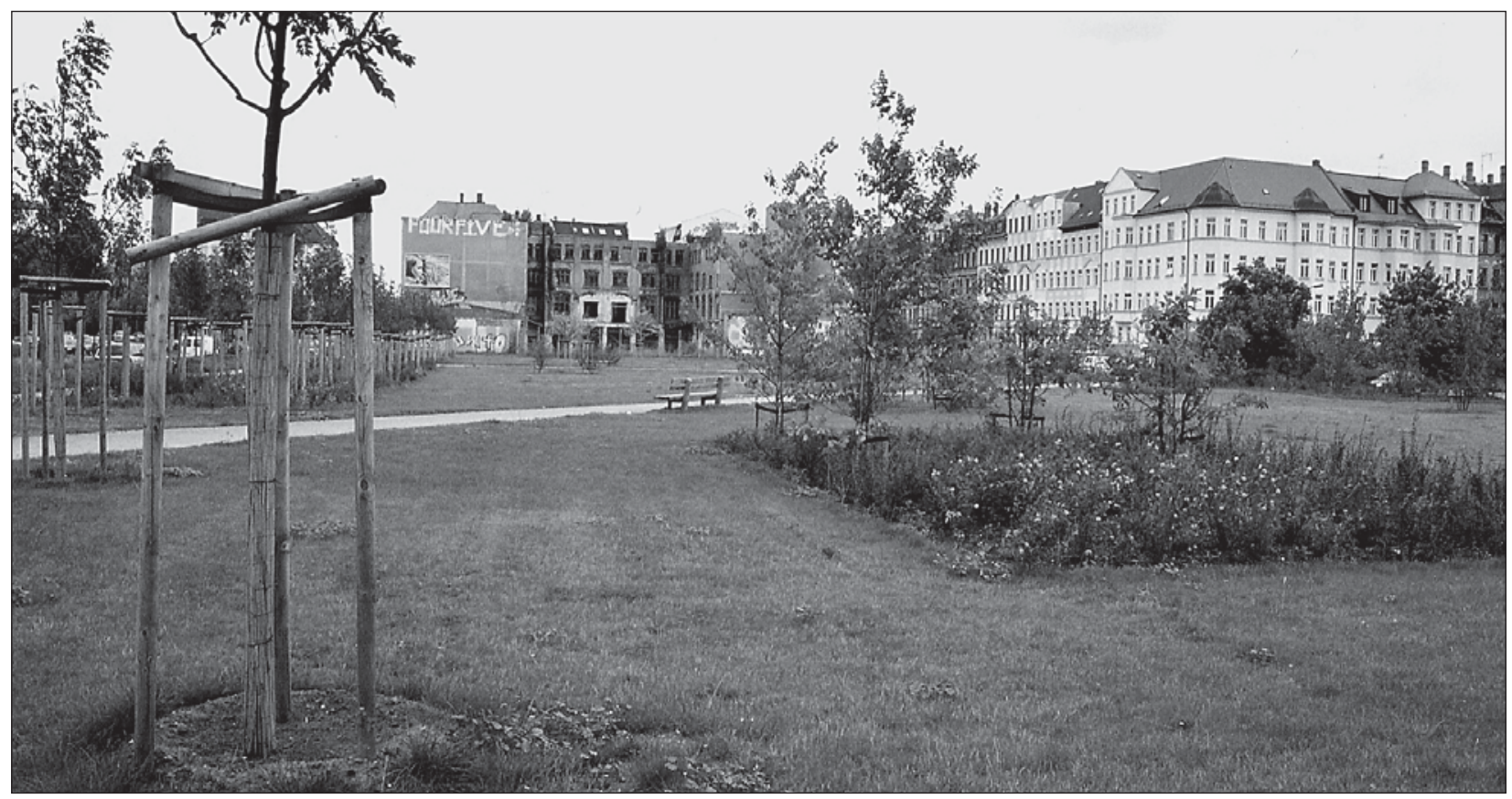

Figure 1: Temporary green space (photo: Stefanie Rößler). 
Planning and funding resources prioritise green space development as simple, successful and appreciated measures. This strategy clearly aims at the stabilisation of affected quarters and, therefore, at new building activities and investments. Accordingly, initial experience shows that if this strategy of urban renewal is successful, then the green spaces which were partly responsible for this uptrend will disappear because of their temporary character, independent of the social, aesthetical and ecological qualities obtained.

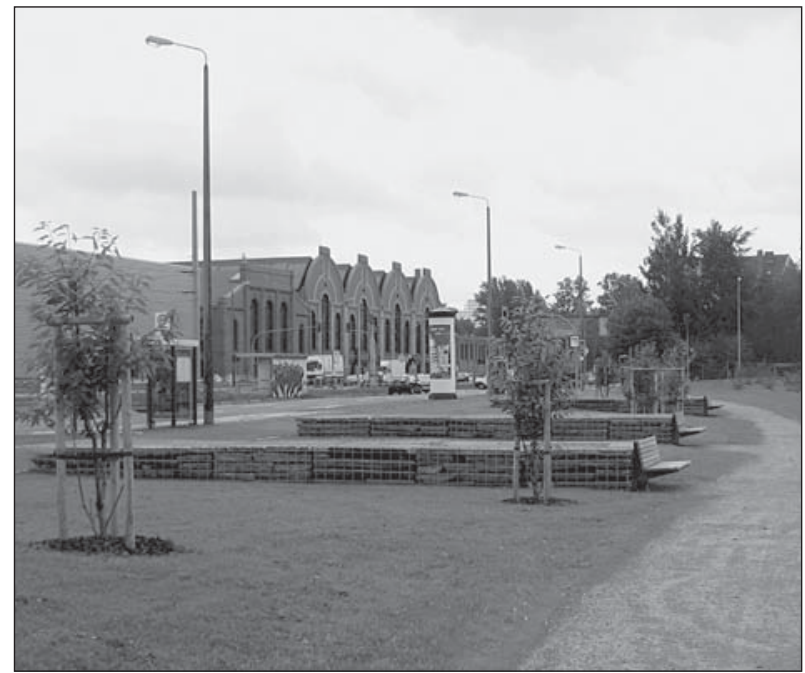

Figure 2: Permanent green space (photo: Stefanie Rößler).

The opposite approach is the long-lasting protection of green spaces. Areas, where new building activities are very improbable, are changed into permanent green spaces by building law. This strategy needs municipal engagement and the financial resources of the local authorities, because private owners are mainly not interested in losing their building laws, which normally means decreasing land values. Nevertheless, this is the only way to increase the proportion of permanent green spaces. From the point of view of green space planning, the permanent development of green spaces alone really means an improvement of the situation and, therefore, it can be classified as a green space strategy. Temporary green spaces are just a means to an end, namely, to urban renewal. Significantly, the implementation of these two strategies differs from the inner city to the shrinking districts: thus, permanent green space development is a typical strategy for the shrinking districts on the edge of the inner city, where the vision of the compact European City has been given up.

\subsection{Types of green spaces in urban restructuring}

In the strongly shrinking areas outside of the inner city, new types of green spaces have also emerged and have been accepted by local planning authorities. According to the dimension of the derelict land and the decreasing financial resources, new ways of designing and using of green spaces need to be applied (Giseke, 2007). So it's not so much a question of the appearance of really new categories of green spaces than it is of new approaches of using and maintaining them. These new approaches may partly express a growing desire for nature based on a new relationship to nature (Dettmar, 2005) and a holistic comprehension of landscape (Sieferle, 2004, Waldheim, 2006). Nevertheless, it is a pragmatic approach that is in accordance with the current framework of shrinking cities. Besides, it is important to be aware of the demands of urban green spaces regarding their structural and social functions (Becker, Giseke, 2004).

Thus, approaches involving forestry and agriculture have been adapted to an urban context. Also, garden and wilderness themes have been translated into the context of urban shrinkage. Following some experiences from the cities, which have been observed in that research, will be presented, underlining the diversity and also innovation of some new approaches for green spaces in shrinking cities.

\section{Urban forestry}

Urban forestry is not that new approach; it's a green space type which is historically a part of several European cities. But in shrinking cities it might get a new relevance: Forest or "forestlike" greening includes the chance to develop sustainable green spaces as stable ecological systems with high benefits for biodiversity. It's also the cheapest method to green an area with very low maintenance costs. Therefore some examples are known, where former building plots at the fringe of large prefabricated housing estates are afforested. That means the urban character completely has given up and secondary natures will be established. The term forest is also used for green space measures which aim at the preservation of the urban structures by strengthening the borders of the former building quarters and therefore a main characteristic of the European City (figure 3). Demolition of vacant houses is especially necessary in simple estates, affected for example by traffic. To preserve these important structures bigger trees, planted in dense rows, might be a way to transform the common urban structure with green walls in a new one.

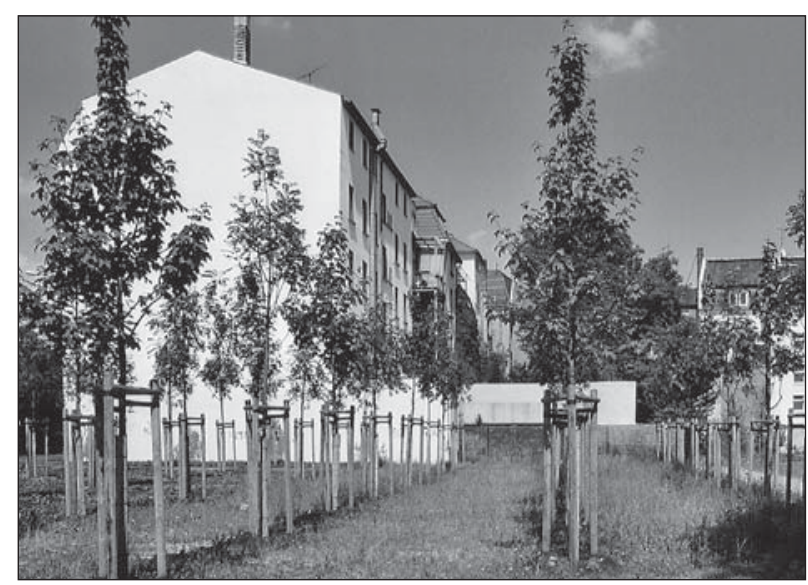

Figure 3: Example of urban forestry in Halle, Germany (photo: Stefanie Rößler).

\section{Urban agriculture}

Urban agriculture is as well as forestry not really a new phenomenon in urban areas. But the challenge to find some cost efficient land uses besides building again spotlights this kind 
of green space. This development is supported by the current development in agriculture in general, characterised by approaches to plant energy crops as renewable resources (figure 4). Besides climate change might influence the growing conditions and again more land for agricultural production is needed. The way agriculture is moving into the city differs from the known way of cultivation. Sometimes it is more the horticultural approach or the experience of rural living. But at the end the pictures look alike. We have to wait if these ways of land use are accepted by the residents.

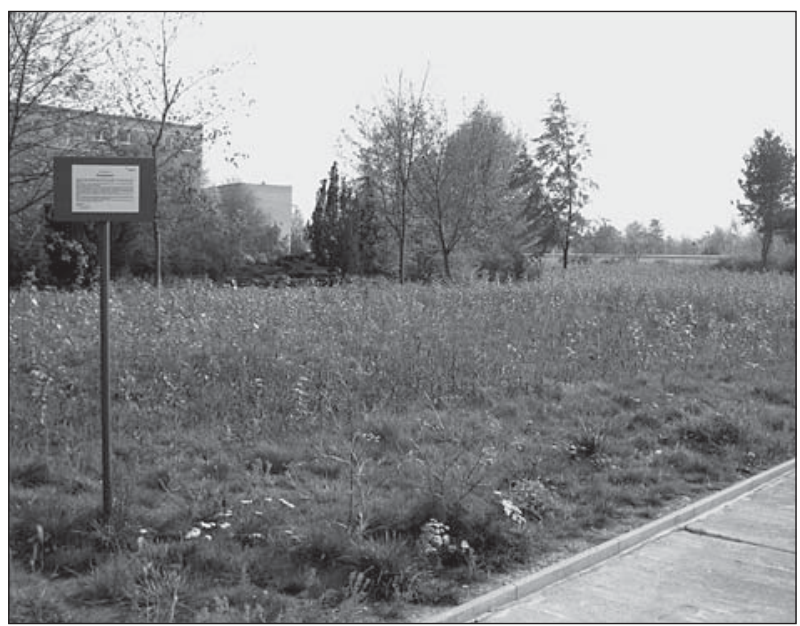

Figure 4: Example of agriculture (energy crops) in a shrinking city (photo: Stefanie Rößler)

\section{Gardens}

The demand for private green spaces is continuing high. Lower densities and the availability of lots also nearby high rise buildings or dense quarters from the Wilheminan period include opportunities for gardening. There is a wide variety of examples for new garden projects in shrinking cities. There are examples which follow the classic approach of allotment gardens (figure 5). To have some partners maintaining the huge amount of green spaces means a possibility for private landlords to reduce costs. Parallel the satisfaction of residents might rise by offering land for private gardening. Therefore it's a double profitable strategy for larger housing companies.

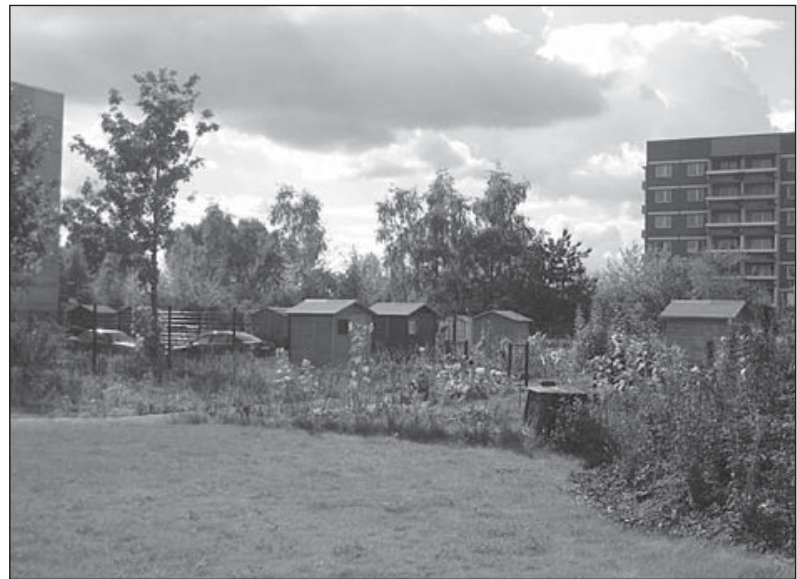

Figure 5: Allotment gardens on vacant lots in Leipzig (photo: Stefanie Rößler).
Gardening is also a topic in older quarters of the shrinking cities. According to differing population structures, demands and urban structures approaches for private and especially collective use of (temporary) vacant lots are spreading (figure 6). The demand for a bit green space near the flat, the idea to strengthen neighbourhoods, the positive impacts for integration of social disadvantaged groups of residents, the wish for harvest self cultivated healthy vegetables or having a place for children's play or meeting - all these might be reasons for creating gardens on vacant lots. There are quite different organisation schemes - but all together are offers with low thresholds in the neighbourhood. Very early examples are known from North American cities beginning in the 1980's (so called community gardens). More and more of these gardens have been developed in Germany during the last years. Not all of them are in shrinking cites. Especially the so called "Gardens of and for migrants" are a successful instrument for integration and communication. But these approaches and examples for neighbourhood initiatives have really good chances for realisation in cities with enough spaces and less economic interests.

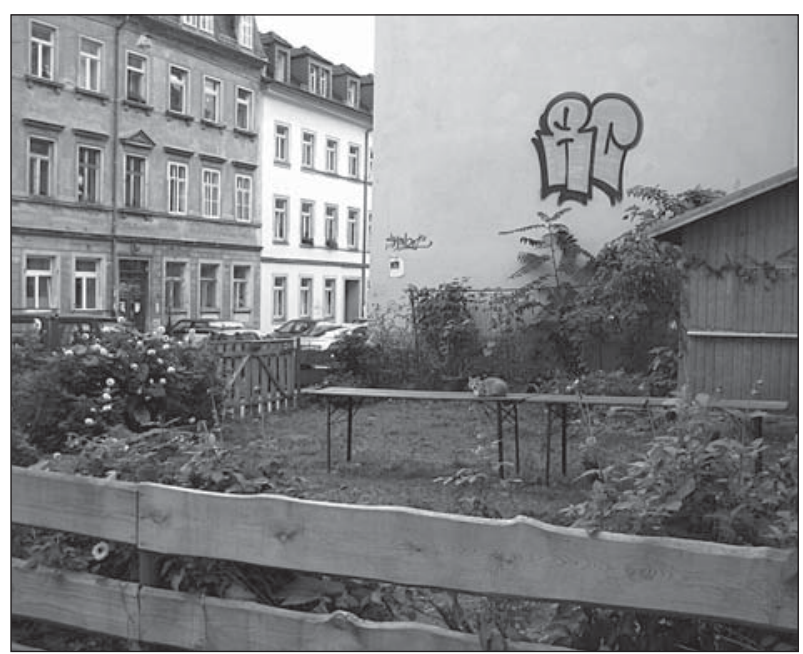

Figure 6: New type of private garden in Dresden, Germany (photo: Stefanie Rößler).

\section{Urban wilderness}

Besides these projects, which all have some kind of tradition in urban areas, also the development of wilderness in shrinking cities is discussed. Being aware the huge amount of open spaces and the less chances to find for all of them users and uses, not to mention any money, wilderness seems to be a kind of logical development for some areas of the city (figure 7). There are no realised examples but the professional discussion shows some tendencies for that approach dealing with the challenge. The ecological qualities and benefits might be high, but we have to think about the requirements of urban form. Is green wilderness which is not useable and accessible really an enrichment of urban structures? Which basic design elements are necessary to make these areas understandable and usable? For sure it depends much on the type of urban quarter, the role within the urban green system as a whole and the acceptance of such uncommon green spaces. But planners have to be aware about the negative impacts which might arise as a perception of decay. So missing ideas or money should not been sold as ecological value. 


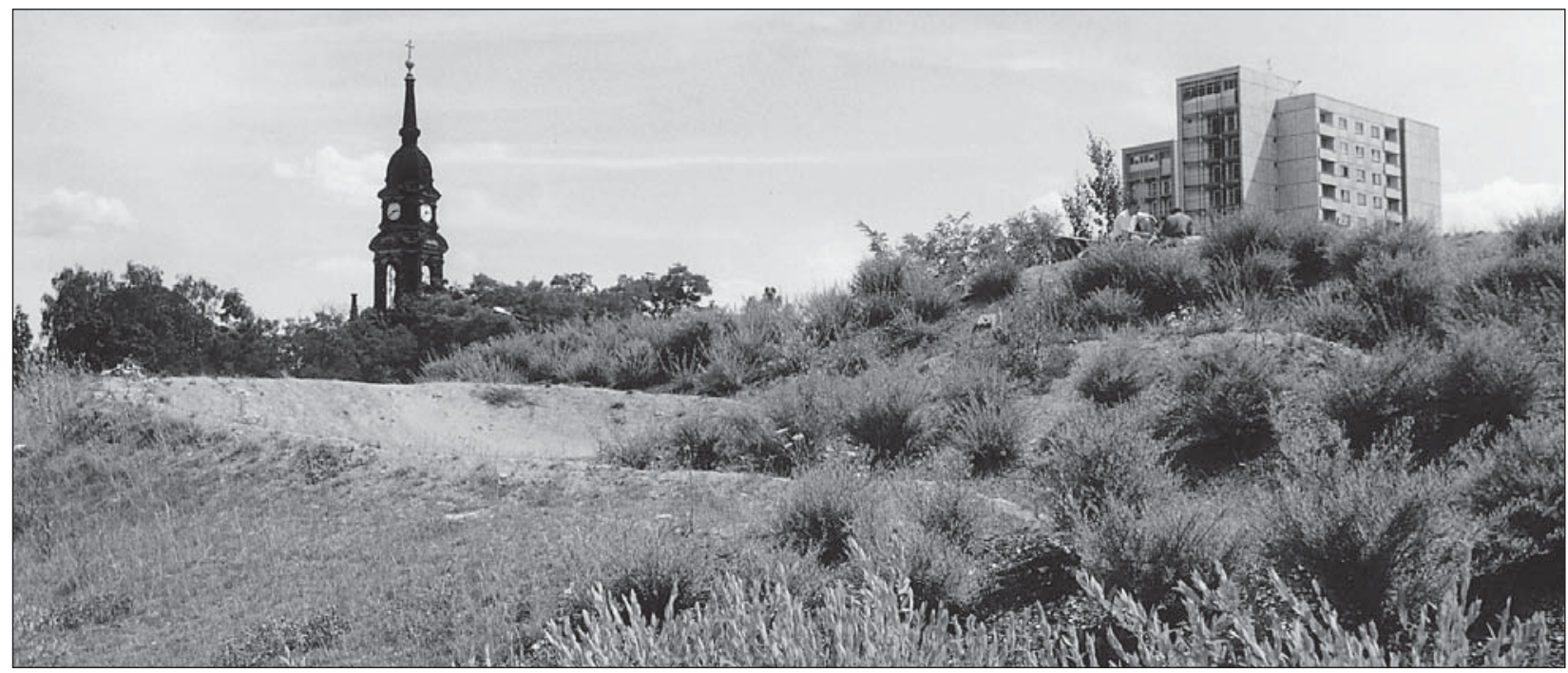

Figure 7: Urban wilderness: Enrichment or sign of decay? (Photo: Stefanie Rößler).

Although common and established types and categories of urban green spaces will not disappear, they will be supplemented by new approaches which fits better to the current demands of budget cutbacks, never known dimensions of open spaces and changing user demands.

\section{Conclusion: challenges and constraints of green space development in shrinking cities}

The analysed city strategies express the necessity and importance of green spaces as structural elements of the urban fabric. The empirical evidence showed clear differences between abstract and general urban models and the implementation in strategies and planning decisions. A difference can be seen between the relevance of green spaces in the implementation of urban restructuring - appreciating green spaces as important parts of sustainable and successful urban restructuring - and the implementation of green space development in the process. Undoubtedly, the relevance of green space development is increasing in shrinking cities but this depends less on the awareness of their benefits in and of themselves than on their contributions to a successful urban renewal. Accordingly, green space planning as an independent discipline with its own objectives might not be strengthened but their contribution to city development might increase. All this leads to a greater relevance of green spaces in shrinking cities but not to an adequate relevance of green space planning. This is especially the case, when green space planning is assumed as an independent and strong sectoral planning, arguing for the value and benefits of green spaces and the need for established expertise. The suspicion might well arise here that green spaces might be used for stopgaps for lacking building development and less because one is convinced of their complex ecological, social and economic values.

\section{References}

Albers, G. (2007) Strukturmodelle für die Stadtentwicklung gerichtet auf Wachstumslenkung - geeignet für Schrumpfungslenkung?, in: Giseke, U., and Spiegel, E. (eds.). Stadtlichtungen. Irritationen, Perspektiven, Strategien, pp. 31-46. Basel, Gütersloh: Birkhäuser, Bauverlag.

Becker, C. W., and Giseke, U. (2004) Wildnis als Baustein künftiger Stadtentwicklung. Garten + Landschaft, 114(2), pp. 22-23.

Blume, T. (2005) New Urban Configurations, in: IBA Office (eds.) The other cities. IBA Stadtumbau 2010. Band 1: Experiment, pp. 111-116. Dessau, Jovis.

Dettmar, J. (2005) Nature-dominated Development in Urban Landscape, in: Institute for Landscape Architecture, E. Z. (eds.) Landscape Architecture in Mutation - essays on urban landscape, pp. 79-97. Zürich, gta Verlag.

Doehler-Behzadi, M., and Schiffers, B. (2004) A Story of Density, in: Lütke Daldrup, E., and Doehler-Behzadi, M. (eds.) PlusMinus Leipzig 2030. Transfoming the City, pp. 32-48. Wuppertal, Müller + Busmann.

Gatzweiler, H. P., Meyer, K., and Milbert, A. (2003) Schrumpfende Städte in Deutschland? Fakten und Trends. Informationen zur Raumentwicklung: Stadtumbau, 10/11, pp. 557-574.

Giseke, U. (2007) Und auf einmal ist Platz. Freie Räume und beiläufige Landschaften in der gelichteten Stadt, in: Giseke, U., and Spiegel, E. (eds.) Stadtlichtungen. Irritationen, Perspektiven, Strategien, pp. 187-217. Basel, Gütersloh: Birkhäuser, Bauverlag.

Hannemann, C. (2003) Schrumpfende Städte in Ostdeutschland - Ursachen und Folgen einer Stadtentwicklung ohne Wirtschaftswachstum. Aus Politik und Zeitgeschichte, 20, pp. 16-23.

Reuther, I. (2002) Leitbilder für den Stadtumbau, in: BMVBW, and BBR (eds.) Fachdokumentation zum Wettbewerb "Stadtumbau Ost": Expertisen zu städtebaulichen und wohnungswirtschaftlichen Aspekten des Stadtumbaus in den neuen Ländern, pp. 12-24. Bonn.

Rößler, S. (2007) Aktuelle Herausforderungen für die Freiraumplanung in schrumpfenden Städten, in: Dettmar, J., and Werner, P. (eds.) Perspektiven und Bedeutung von Stadtnatur für die Stadtentwicklung, pp. 117-127. Darmstadt, Kompetenznetzwerk Stadtökologie.

Sieferle, R. P. (2004) Die totale Landschaft. TOPOS, 47, pp. 6-13.

Waldheim, C. (2006) The Landscape Urbanism Reader. New York, Princeton Architectural Press. 